\title{
Monitoring and Assessing of Spring Water Quality in Southwestern Basin of Jordan
}

\author{
Omar A. Al-Khashman"1,2, Hani M. Alnawafleh ${ }^{1 *}$, Ahmad M. Abu Jrai ${ }^{1}$, Ala'a H. Al-Muhtaseb ${ }^{3}$ \\ ${ }^{1}$ Faculty of Engineering, Al-Hussein Bin Talal University, Ma'an, Jordan \\ ${ }^{2}$ Faculty of Engineering, Tafila Technical University, Tafila, Jordan \\ ${ }^{3}$ Department of Petroleum and Chemical Engineering, Sultan Qabos University, Muscat, Oman \\ Email: *hanialnawafleh@ahu.edu.jo
}

How to cite this paper: Al-Khashman, O.A., Alnawafleh, H.M., Jrai, A.M.A. and Al-Muhtaseb, A.H. (2017) Monitoring and Assessing of Spring Water Quality in Southwestern Basin of Jordan. Open Journal of Modern Hydrology, 7, 331-349. https://doi.org/10.4236/ojmh.2017.74019

Received: September 26, 2017

Accepted: October 28, 2017

Published: October 31, 2017

Copyright ( $) 2017$ by authors and Scientific Research Publishing Inc. This work is licensed under the Creative Commons Attribution International License (CC BY 4.0).

http://creativecommons.org/licenses/by/4.0/

\begin{abstract}
This study was undertaken to assess the physical, chemical and hydrochemical quality of spring water in the southwestern basin of Jordan during a 60-month follow up monitoring study (April 2009 to April 2014). The samples were analyzed for temperature, conductivity, dissolved oxygen, $\mathrm{pH}$, major cations, major anions and trace metals. The results show that there were considerable variations among the analyzed samples with respect to their physical and chemical parameters, which lie below the maximum permissible levels of the Jordanian and World Health Organization (WHO) drinking water standards. This study shows that the trace metals of spring water in the study area do not generally pose any health or environmental issues. The assessment of water samples indicates that groundwater, in general, is chemically suitable for drinking and agricultural uses.
\end{abstract}

\section{Keywords}

Water Quality, Springs, Hydrochemistry, Metals, Jordan

\section{Introduction}

\subsection{The Study Area: An Overview}

Water demand for industrial, domestic and agricultural uses increases with population growth. When the demand exceeds the naturally renewable supply, water shortage occurs in the area. However, excessive groundwater withdrawals lead to water shortage, and to decline in the water quality due to saltwater intrusion [1]. Groundwater sustainability may refer to the development and use of the resource in a manner that can be maintained for an indefinite time without causing unacceptable environmental, economic, or social consequences [2]. Surface 
and groundwater represent an important source for drinking and irrigation purposes and the quality is currently threatened by the combination of over-abstraction and physical, chemical and microbiological contamination [3] [4].

The scarcities of freshwater in Jordan and the continuous increase in demand and hence supply play a major role in the development of water quality in Jordan. The groundwater resources in Jordan consist of both renewable and fossil waters which extend in aquifers at different depths throughout the country [5]. Groundwater in Jordan represents the major source of drinking water and therefore, leaching of agricultural and industrial pollutants is a growing concern, hence groundwater quality monitoring is an essential step in characterizing groundwater systems [6].

The pollution and scarcity of water resources are the most important challenges facing the country, while pollution of water is attributed to high population growth (the average population growth is around 3.5\% per year), agricultural activities, industrialization and arid to semiarid climate [7]. These Factors resulted in infiltration of wastewater into spring and groundwater resources. In towns and villages of Jordan, wastewater from septic tanks and cesspools infiltrating into the groundwater accelerates the pollution problems. This increases the pressure on the water resources by increasing the salinity, nitrate, sulfate, ammonia, phosphate and organic materials contents.

The study area is considered as a very arid to semiarid area (Figure 1). The area is marked by sharp seasonal variation in both temperature and precipitation. The area extends $10 \mathrm{~km}$ east the Dead Sea from Karak to Wadi Musa including Wadi Araba with an annual rainfall of about $60 \mathrm{~mm}$ /year in Ghore Safi area to $350 \mathrm{~mm} /$ year in Petra area [8].

This area is selected because it extends along the southwestern basin which is an important water basin in Jordan. The area is influenced by industrial activities, such as potash and cement industries, in addition to agricultural and vehicles activities.

Spring water within the study area is one of the major sources for drinking water and irrigation activities. The average discharge in the springs ranges from $0.2 \mathrm{~m}^{3} / \mathrm{h}$ in Jghaileyyeh spring to $147.7 \mathrm{~m}^{3} / \mathrm{h}$ in El-Ghweir spring (Table 1). The surface water is composed of ephemeral wadis that drain their water during winter. Approximately $89 \%$ of the total amount of the rainfall water precipitation over the area evaporates into the atmosphere [10]. The rest flows into wadis as flood flow and partly recharges the groundwater aquifers.

The study area is subdivided into several sub-drainage areas. Some of these drainage areas are perennial and the others are intermittent depending on the intensity and duration of the rainfall as well as the topography and geology of the area. In time of extensive rainfall, runoff concentrates in the wadis and flow out of the recent sediments (alluvial fans). Part of the runoff reaches to Wadi Araba and the rest infiltrates into the wadis sediments and feeds the groundwater [10] [12]. The groundwater resources in the investigated area consist of 15 


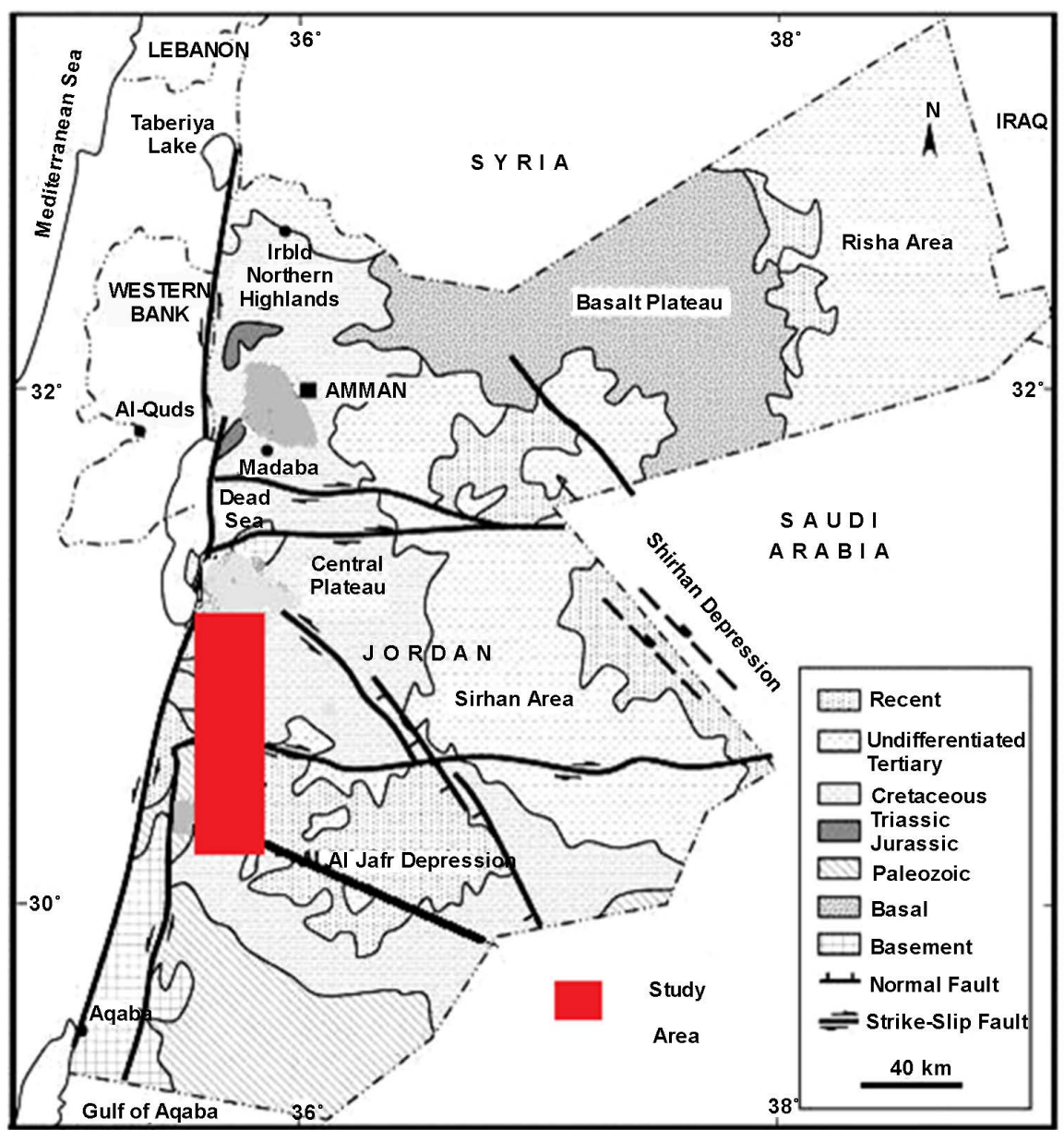

Figure 1. Geological setting map of Jordan [9]. The study area is highlighted.

springs emerging from Upper Cretaceous aquifers. The goals of the present research is to study the chemical, physical and biological characteristics of spring water and to determine the deterioration in water quality, identify sources of pollutants and characterize the suitability of the springs water for drinking and agricultural purposes. One of the objectives for this work is to characterize the present status of water resources and to determine if the resources are changing over time. This work is part of a long-term program designed to establish the inventories of groundwater quality in the study area.

\subsection{Geology of the Study Area}

The geology of the investigated area is built of a series of rock units ranging in age from Cambrian to recent with missing of carboniferous to Jurassic [5] [13]. The Kurnub group composed primarily of sandstones cropping out along the rift side at Tafila, Karak and Shoubak [14]. The group is more or less consistent in lithology throughout Jordan, although it becomes slightly more terrestrial southward and eastwards of the study area [13] [15]. The groundwater in the study area is derived entirely from precipitation that falls over its entire catchment area [5] [10]. This is considered as the main water resource, which can be 
Table 1. Major springs with their average discharge at Northern Wadi Araba basin [11].

\begin{tabular}{|c|c|c|c|c|c|c|c|}
\hline \multirow{2}{*}{ No. } & \multirow{2}{*}{ Code } & \multirow{2}{*}{ Spring name } & \multicolumn{2}{|c|}{ Coordinate/PG } & \multirow{2}{*}{$\begin{array}{l}\text { Altitude } \\
\text { (m) }\end{array}$} & \multirow{2}{*}{$\begin{array}{c}\text { Discharge } \\
\mathrm{m}^{3} \cdot \mathrm{h}^{-1}\end{array}$} & \multirow{2}{*}{$\begin{array}{l}\text { Aquifer } \\
\text { type }\end{array}$} \\
\hline & & & North & East & & & \\
\hline $1 \mathrm{~S}$ & DG 0556 & Shalha & 1027.900 & 207.500 & 900 & 6.8 & $\mathrm{~A} 1-\mathrm{A} 2$ \\
\hline $2 S$ & DB 0562 & Unsur & 1027.700 & 207.700 & 1000 & 6.7 & $\mathrm{~A} 1-\mathrm{A} 2$ \\
\hline $3 \mathrm{~S}$ & DB 0556 & Um-Garyah & 1027.900 & 208.500 & 995 & 2.6 & A7-B2 \\
\hline $4 \mathrm{~S}$ & DB 0610 & Karma & 1032.000 & 210.000 & 870 & 3.1 & A7-B2 \\
\hline $5 \mathrm{~S}$ & DC 0564 & Reah & 1015.300 & 210.100 & 870 & 1.6 & A7-B2 \\
\hline $6 \mathrm{~S}$ & DB 0614 & Marwan & 1035.200 & 213.700 & 850 & 2.3 & A7-B2 \\
\hline $7 \mathrm{~S}$ & DB 0548 & El-Hasdeh & 1028.800 & 204.100 & 1020 & 2.2 & $\mathrm{~K}$ \\
\hline $8 \mathrm{~S}$ & DB 0546 & El-Balad & 1028.000 & 204.100 & 1000 & 2.4 & $\mathrm{~K}$ \\
\hline $9 \mathrm{~S}$ & DB 0582 & Um Ruweim & 1026.100 & 205.800 & 1005 & 3.3 & $\mathrm{~A} 1-\mathrm{A} 2$ \\
\hline $10 \mathrm{~S}$ & DC 0602 & El-Mour & 1025.100 & 204.200 & 1200 & 1.1 & A7-B2 \\
\hline $11 \mathrm{~S}$ & DB 0572 & Um-Keis & 1028.300 & 206.500 & 1280 & 13.8 & $\mathrm{~A} 1-\mathrm{A} 2$ \\
\hline $12 \mathrm{~S}$ & DC 0566 & El-Ubour & 1016.400 & 208.500 & 930 & 8.0 & K \\
\hline $13 \mathrm{~S}$ & DC 0562 & Gharandel & 1014.100 & 212.700 & 1340 & 32.8 & $\mathrm{~A} 1-\mathrm{A} 2$ \\
\hline $14 \mathrm{~S}$ & DC 0542 & El-Rahadiya & 1012.900 & 210.700 & 1440 & 3.2 & $\mathrm{~A} 1-\mathrm{A} 2$ \\
\hline $15 S$ & DC 0540 & Lahdha & 1012.300 & 207.000 & 1414 & 1.3 & $\mathrm{~A} 1-\mathrm{A} 2$ \\
\hline $16 \mathrm{~S}$ & $\mathrm{AE} 22$ & Al-Ghweir & 200.950 & 2.750 & 660 & 147.7 & $\mathrm{~K}$ \\
\hline $17 \mathrm{~S}$ & EA 23 & Al-Dathneh & 201.000 & 2.770 & 680 & 40.4 & $\mathrm{~K}$ \\
\hline $18 \mathrm{~S}$ & DE 0584 & Zubeidiya & 208.300 & 10.500 & 1210 & 2.7 & $\mathrm{~A} 1-\mathrm{A} 2$ \\
\hline $19 \mathrm{~S}$ & DE 0586 & Khalid & 209.300 & 10.500 & 1140 & 4 & A7-B2 \\
\hline $20 \mathrm{~S}$ & DE 0550 & Ifjeij (Fouqa) & 208.000 & 993.700 & 1240 & 3.8 & B4 \\
\hline $21 \mathrm{~S}$ & DE 0552 & Ifjeij (Tehta) & 208.200 & 994.000 & 1180 & 2.4 & B4 \\
\hline $22 \mathrm{~S}$ & DE 0554 & Liwainat & 203.500 & 996.800 & 1220 & 0.9 & B3 \\
\hline $23 \mathrm{~S}$ & DF 0546 & Jenania & 197.000 & 988.200 & 1330 & 3.2 & A1-A6 \\
\hline $24 \mathrm{~S}$ & DF 0548 & Hawalah & 198.000 & 988.200 & 1340 & 4.2 & A7-B2 \\
\hline $25 \mathrm{~S}$ & DE 0548 & Essider & 204.200 & 996.300 & 1125 & 11.4 & B3 \\
\hline $26 \mathrm{~S}$ & DE 0546 & Mugarayyeh & 203.700 & 995.600 & 1250 & 6.7 & A7-B2 \\
\hline $27 \mathrm{~S}$ & DE 0544 & Aqeel & 205.300 & 993.700 & 1145 & 10.7 & B3 \\
\hline $28 \mathrm{~S}$ & DF 0540 & Shammakh & 198.800 & 989.000 & 1320 & 4.2 & A7-B2 \\
\hline $29 \mathrm{~S}$ & DE 0558 & El-A'Asi & 203.800 & 993.600 & 1300 & 4.2 & A7-B2 \\
\hline $30 \mathrm{~S}$ & DE 0556 & Jghaileyyeh & 202.800 & 996.900 & 1300 & 0.2 & A7-B2 \\
\hline $31 \mathrm{~S}$ & DG 20 & Musa & 197.700 & 970.600 & 1310 & 25.8 & A7-B2 \\
\hline $32 \mathrm{~S}$ & DG 21 & Boi'Bo & 197.500 & 970.800 & 1275 & 4.8 & A7-B2 \\
\hline $33 \mathrm{~S}$ & DG 22 & Jilwack & 197.600 & 971.300 & 1275 & 7.1 & A7-B2 \\
\hline $34 \mathrm{~S}$ & DG 23 & Ras Jilwack & 197.800 & 971.500 & 1350 & 2.5 & A7-B2 \\
\hline $35 \mathrm{~S}$ & DG 24 & Sakeeneh & 197.700 & 971.300 & 1320 & 4.3 & A7-B2 \\
\hline $36 \mathrm{~S}$ & DG 26 & Shallaleh & 197.300 & 970.900 & 1250 & 2.6 & A7-B2 \\
\hline $37 \mathrm{~S}$ & DG 27 & Es-Sarab & 196.300 & 970.200 & 1185 & 0.9 & A7-B2 \\
\hline $38 \mathrm{~S}$ & DG 30 & Zarraba & 195.700 & 970.800 & 1085 & 3.4 & A1-A6 \\
\hline $39 S$ & DG 56 & Ammun & 194.200 & 968.200 & 1300 & 1.6 & A1-A6 \\
\hline $40 \mathrm{~S}$ & DH 36 & Saboor & 194.200 & 964.100 & 1540 & 0.5 & A1-A6 \\
\hline
\end{tabular}


developed in the area. The groundwater flow direction within the study area is from the east and west toward the central part of Wadi Araba. It is governed by the two base levels of the Dead Sea in the north and the Red Sea in the south [16]. The lithological units are composed of the $40-480 \mathrm{~m}$ thick sedimentary rocks including Cretaceous and Tertiary formations [5] [13]. Those formations are composed of limestone, marl, chert, marly limestone and chalky limestone with chert intercalation [9].

Structurally, the area is intensively faulted and folded as a result of various tectonic activities. The basin is affected by many major faults and complicated fault zones. These faults trend E-W, WNW-ESE, N-S, NNE and NE-SW directions. Most of the folds in the basin are found in the Upper Cretaceous and Tertiary carbonate rocks. These folds were affected by compression forces, which produced folding deformation [16].

\subsection{Hydrogeology of the Study Area}

Groundwater is considered as the main water resources in the study area, discharged mainly from precipitation to the entire catchment area. The groundwater is the most common developed source among the various water resources in the country because it is reliable in yield and of good quality. The main aquifer system in the investigated area is of Cretaceous [5] [10] and consists of the following subsystems:

1) Lower aquifer systems: this system is composed of sandstone and party limestone of lower Cretaceous age together with older sandstones of Silurian and Ordovician. It consists of massive, white and varicolored sandstone reaching in total thickness about $300 \mathrm{~m} \mathrm{[5]} \mathrm{[9]} \mathrm{[15].} \mathrm{Aquifer} \mathrm{systems} \mathrm{are} \mathrm{found} \mathrm{along} \mathrm{the} \mathrm{rift}$ side within the investigated area. The sequences are jointed and well cemented to friable and highly permeable; therefore possess good aquifer properties (Table 2).

2) Middle aquifer systems: This system is composed of Upper Cretaceous rock unit that comprises Amman, Wadi Al-Sir and Hummar hydraulic complex [16]. This aquifer system is part of the main aquifers (A1/A2, A3, A4, A5/A6, A7/B2, B2 and B4). Table 2 shows the geological and hydrogeological classification of these units into aquifer and aquiclude [15] [17]. The A1/A2 is composed of marl, limestone, dolomitic limestone and grey mudstone containing plant remains and gypsum lamina and marl stone forming a fair aquifer [9] [18].

The A3 is composed of marl inter-bedded with limestone and mudstone with beds of laminated fibrous and locally nodular gypsum and is considered as a poor aquifers. Whereas, the A4 consists of crystalline dolomitic limestone and grey limestone. The later is rich in micrite and chert nodules. This formation is considered as highly permeable, when fractured and jointed, forming a good aquifer [5] [15] [19]. The A5/A6 consists of marly limestone and marl with few bands of dolomitic limestone, dolomite, and limestone forming a good aquifer because of high jointing nature. The A7/B2 formation is considered to be one of the most important groundwater reservoirs in the investigated area. It is 
Table 2. Hydrgeological classification of rock types in the study area [17].

\begin{tabular}{|c|c|c|c|c|c|}
\hline Period & Group & Formation & Symbol & General Lithology & $\begin{array}{c}\text { Hydrogeological } \\
\text { Classification }\end{array}$ \\
\hline \multirow[t]{4}{*}{ Quaternary } & & $\begin{array}{l}\text { Alluvial } \\
\text { deposits }\end{array}$ & JA & $\begin{array}{c}\text { Sand, gravel, } \\
\text { clay, lacustrine } \\
\text { sediments, marl }\end{array}$ & Aquifer-aquiclude \\
\hline & & Basalts & BS & Basalt, tuff, clay & Aquifer \\
\hline & & Sirhan & S1 S2 & $\begin{array}{l}\text { Sandy marl, sandstone, } \\
\text { clay, marl }\end{array}$ & Aquifer-aquitard \\
\hline & & Basalts & B4-B1 & Basalt, tuff, clay & Aquifer \\
\hline \multirow[t]{5}{*}{ Tertiary } & & $\begin{array}{c}\text { W. } \\
\text { Shallaha }\end{array}$ & B5 & $\begin{array}{c}\text { Marl, clay, } \\
\text { limestone, chert }\end{array}$ & Aquitard \\
\hline & Balqa & $\begin{array}{c}\text { Rijam } \\
\text { B4 }\end{array}$ & & $\begin{array}{l}\text { Chalky limestone } \\
\text { with chert }\end{array}$ & Aquifer \\
\hline & & Muwaqqer & B3 & $\begin{array}{l}\text { Bituminous marl, } \\
\text { chalky chert, shale }\end{array}$ & Aquitard \\
\hline & & Amman & B2 & $\begin{array}{l}\text { Marly limestone, } \\
\text { phosphates, chert }\end{array}$ & Aquifer \\
\hline & & $\begin{array}{l}\text { Umm } \\
\text { Ghudran }\end{array}$ & B1 & Marl, shale & Aquitard \\
\hline \multirow[t]{5}{*}{ Late Cretaceous } & & $\begin{array}{l}\text { Wadi Es } \\
\text { Sir }\end{array}$ & A7 & Marly limestone & Aquifer \\
\hline & & Shueib & A5-A6 & $\begin{array}{l}\text { Argillaceous dolomite } \\
\text { and limestone. }\end{array}$ & \\
\hline & Ajlun & Hummar & A4 & $\begin{array}{l}\text { Limestone, dolomite } \\
\text { limestone. }\end{array}$ & Aquitard \\
\hline & & Fuheis & A3 & Shale, sandstone & \\
\hline & & Na'ur & A1-2 & Dolomitized carbonate. & \\
\hline Early Cretaceous & & Kurunb & K & Sandstone & Aquifer \\
\hline Jurassic & & Huni & & Sandy silt sand, shale & Aquiclude-aquifer \\
\hline Triassic & & Ma'in & & Siltstone, mudstone & Aquiclude \\
\hline Cambrian-Silurian & & & & $\begin{array}{l}\text { Sandstone, dolomite } \\
\text { limestone }\end{array}$ & Aquifer \\
\hline
\end{tabular}

composed of limestone, marly limestone with chert bands, chalk, and dolomite limestone.

\section{Materials and Methods}

Water samples were collected monthly using polyethylene bottles from 40 springs covering the area over the period from April 2009 to April 2014. Samples numbers and samples names are shown in Table 1 . A total of 1800 samples were collected during a five years monitoring program. The water samples were analyzed for their physical and chemical parameters according to the methods that suggested by Rand et al. [20] and Al-Khashman [21]. Monthly samples were collected to monitor changes in the water quality caused by the seasonal hydrological cycle.

All glassware and polyethylene bottles were soaked in $20 \% \mathrm{HNO}_{3}$ for one day 
and rinsed several times with deionized water before use. During sampling, polyethylene sample bottles were rinsed in clear spring water several times and then filled to the top to minimize entrapment of air in water spring samples [22]. On the other hand, the samples for metals determination were preserved with nitric acid. On-site measurements included temperature, $\mathrm{pH}$, and electrical conductivity (EC) and dissolved oxygen (DO). Conductivity measurements were carried out with 470 JENWAY conductivity meter with temperature compensation, while the $\mathrm{pH}$ values were measured in the field using 370 JENWAY $\mathrm{pH}$-meters. Calibration was always carried out before measurement using standards buffer solutions of $\mathrm{pH} 4.00$ and 7.00 respectively. Dissolved oxygen values were measured in the field using DO-meter (WTW equipment). The total dissolved solids (TDS) were measured by TDS meter (Oakton Control Co, USA). Major anions $\left(\mathrm{F}^{-}, \mathrm{Cl}^{-}, \mathrm{NO}_{3}^{-}, \mathrm{PO}_{4}^{3-}, \mathrm{SO}_{4}^{2-}\right)$ were analyzed by 100 Dionex Ion Chromatography instruments equipped with AG4A-SC guard column, AS4ASC separating column, SSR1 anion self-generation suppresser and conductivity detector. Major cations $\left(\mathrm{Ca}^{2+}, \mathrm{Mg}^{2+}, \mathrm{Na}^{+}, \mathrm{K}^{+}\right)$were measured by 800 Varian Flame Atomic Absorption Spectrophotometer. The concentrations of cations were determined using a CS12 analytical column, CG 12 guard column, using $20 \mathrm{~m} \mu$ $\mathrm{CH}_{4} \mathrm{SO}_{3}^{-}$. The concentration of bicarbonate was measured by titration with 0.01 hydrochloric acid using methyl orange as indicator. Trace metals $\left(\mathrm{Fe}^{2+}, \mathrm{Al}^{3+}\right.$, $\left.\mathrm{Mn}^{2+}, \mathrm{Cu}^{2+}, \mathrm{Ni}^{2+}, \mathrm{Zn}^{2+}, \mathrm{Pb}^{2+}\right)$ were analyzed with Graphite Furnace using GTA 100 instruments. The GF-AAS was calibrated using the method of the standard addition. The standard solutions of the anions, cations, and trace metals as well as blank samples were prepared with different concentrations. All standard solution were made daily by diluting the stock solutions with $0.01 \mathrm{M} \mathrm{HNO}_{3}$ [23], which was prepared from analytical grade $\mathrm{HNO}_{3}$ solution that obtained from Merck. A quality control procedure, including, recalibration of the instruments, analysis of triplicate samples and recovery test of standard reference material was used to control data quality [20]. All chemicals and reagent used were of the analytical grade unless otherwise stated. Deionized water (Milli-Q $18.2 \mu \mathrm{s} / \mathrm{cm}$ ) was used for all dilutions.

To prevent the sample contamination with trace metals, all the glassware, pyrex and plastic containers were washed several times with soap, deionized water and treated with $0.01 \mathrm{M} \mathrm{HNO}_{3}$ and finally rinsed with ultra-pure water. After analysis the accuracy of these standards were within $\pm 7 \%$. The numerical simulation model PHREEQ was used to set up the hydrological components of the groundwater, especially the saturation indices of minerals (calcite, dolomite, gypsum and anhydrate) to test the saturation of minerals in water samples.

\section{Results and Discussion}

\subsection{Chemical Characteristics of Water}

A Total of 1800 water samples were collected from forty representative springs in southwestern part of Jordan during the studying period, April 2009 to April 2014. The statistical summaries of volume-weighted mean concentrations of 
physical and chemical parameters are presented in Table 3 . The ratio of total anions to that of cations (( $\sum$ anions $) /\left(\sum\right.$ cations $\left.)\right)$ was used as an indicator for the completeness of measured parameters [24]. The average equivalent sum of cations to that of anions ( $\sum$ anions $) /\left(\sum\right.$ cations) was found to be $0.83 \pm 0.21$. Also, for the set of samples considered in this study, linear regression of cation sum on anion sum resulted in a variance $R^{2}$ of 0.89 , indicating that the quality of the data was satisfactory. The in-situ measured temperature for the water samples ranges between $16.31^{\circ} \mathrm{C} \pm 1.73^{\circ} \mathrm{C}$ in Sakeeneh spring in the wet season to $24.30^{\circ} \mathrm{C} \pm$ $3.28^{\circ} \mathrm{C}$ in Jghaileyyeh spring in the dry season, with a median value of $19.57^{\circ} \mathrm{C} \pm$ $1.94^{\circ} \mathrm{C}$. The variation in the recorded temperature for all springs in the study area was mainly a result of varying elevation above sea level from which the springs emerged [10].

The $\mathrm{pH}$ values in all sampling sites were in the range of 6.69 in El-Rahadiya spring to 8.23 in Jilwack spring, with a median value of $7.73 \pm 0.35$. The variations in the measured $\mathrm{pH}$ values of different springs were mainly caused by increases in the bicarbonate concentration in the water. The median values of $\mathrm{pH}$ in spring water samples were found to comply with the Jordanian standards for drinking water [25] and WHO [26] [27] drinking water standards (Table 4).

Electrical conductivity (EC) of spring water ranges from $510 \mu \mathrm{s} / \mathrm{cm}$ in Hawalah spring to $1215 \mu \mathrm{s} / \mathrm{cm}$ in Sakeeneh spring with a median value of $761 \pm 177.2$ $\mu \mathrm{s} / \mathrm{cm}$ at $25^{\circ} \mathrm{C}$. The high conductivity of the water samples in Tafila basin was corresponding to the high concentrations of dominant ions, which result from ion exchange and solubility of rocks in aquifer [23] [28]. Dissolved Oxygen (DO) varied in the range from $3.25 \mathrm{mg} / \mathrm{l}$ to $6.70 \mathrm{mg} / \mathrm{l}$.

Total Dissolved Solid (TDS) values in the spring water varied from $323 \mathrm{mg} / \mathrm{l}$ in Hawalah spring to $728 \mathrm{mg} / \mathrm{l}$ in Sakeeneh spring (Figure 2). In general, all TDS values of the spring water fall within the permissible limit of Jordanian standards for drinking water [25]. The results showed that there is an increasing tendency in the TDS values in the dry seasons compared to the wet seasons except for April as TDS is higher than that of June.

The calcium concentration varied from $50 \mathrm{mg} / \mathrm{l}$ in Hawalah spring to $140 \mathrm{mg} / \mathrm{l}$ in Al-Ghweir spring in the wet season, with a median value of $81.27 \pm 21.0 \mathrm{mg} / \mathrm{l}$. The high values of calcium in the dry season in Al-Ghweir spring are due to the dissociation of calcium from the sedimentary carbonate rocks and soils. The concentration of sodium in the water samples ranges from $17 \mathrm{mg} / \mathrm{l}$ in Um-Keis spring to $44.65 \mathrm{mg} / \mathrm{l}$ in El-Hasdeh spring, with a median value of $26.53 \pm 7.31$ $\mathrm{mg} / \mathrm{l}$ (Table 3). The high concentration of sodium in water samples in the summer season resulted from wastewater infiltration and uses of fertilizers in agricultural activities around the water springs. The decrease in sodium concentrations from dry to wet seasons reflects the dilution of groundwater by rainwater. Sodium ion makes a relatively medium contribution compared to calcium and magnesium.

Anions such as chloride, sulfate and nitrate were the major inorganic components deteriorating the drinking-water quality of the groundwater. The spring 
Table 3. Statistical analysis of physical, chemical and biological parameters of spring water samples, $\mathrm{n}=1440$ samples.

\begin{tabular}{|c|c|c|c|c|c|}
\hline Parameters & Units & Minimum & Maximum & Mean & St.Dev \\
\hline $\mathrm{T}$ & $\left({ }^{\circ} \mathrm{C}\right)$ & 16.31 & 24.30 & 19.57 & 1.93 \\
\hline $\mathrm{pH}$ & - & 6.69 & 8.23 & 7.73 & 0.35 \\
\hline $\mathrm{EC}$ & $\mu \mathrm{S} / \mathrm{cm}$ & 510.00 & 1215.00 & 761.00 & 177.00 \\
\hline DO & $\mathrm{mg} / \mathrm{l}$ & 3.25 & 6.70 & 4.63 & 0.79 \\
\hline TDS & $\mathrm{mg} / \mathrm{l}$ & 323.28 & 728.47 & 482.00 & 110.00 \\
\hline $\mathrm{TH}$ & $\mathrm{mg} / \mathrm{l}$ & 199.00 & 475.00 & 306.00 & 63.61 \\
\hline $\mathrm{Ca}^{2+}$ & $\mathrm{mg} / \mathrm{l}$ & 50.00 & 140.00 & 81.27 & 21.00 \\
\hline $\mathrm{Mg}^{2+}$ & $\mathrm{mg} / \mathrm{l}$ & 16.00 & 36.00 & 25.23 & 5.05 \\
\hline $\mathrm{Na}^{+}$ & $\mathrm{mg} / \mathrm{l}$ & 17.00 & 44.65 & 26.53 & 7.31 \\
\hline $\mathrm{K}^{+}$ & $\mathrm{mg} / \mathrm{l}$ & 1.20 & 13.50 & 5.03 & 2.78 \\
\hline $\mathrm{HCO}_{3}^{-}$ & $\mathrm{mg} / \mathrm{l}$ & 120.00 & 301.00 & 187.66 & 49.48 \\
\hline $\mathrm{Cl}^{-}$ & $\mathrm{mg} / \mathrm{l}$ & 52.00 & 158.00 & 87.63 & 23.60 \\
\hline $\mathrm{NO}_{3}^{-}$ & $\mathrm{mg} / \mathrm{l}$ & 27.00 & 130.00 & 79.05 & 24.55 \\
\hline $\mathrm{SO}_{4}^{2-}$ & $\mathrm{mg} / \mathrm{l}$ & 42.00 & 163.50 & 85.38 & 26.82 \\
\hline $\mathrm{F}^{-}$ & $\mathrm{mg} / \mathrm{l}$ & 0.66 & 4.32 & 1.88 & 0.94 \\
\hline $\mathrm{PO}_{4}^{3-}$ & $\mathrm{mg} / \mathrm{l}$ & 0.63 & 6.35 & 3.16 & 1.58 \\
\hline SAR & - & 0.43 & 1.85 & 1.63 & 0.17 \\
\hline$\% \mathrm{Na}$ & & 9.86 & 27.65 & 18.76 & 4.72 \\
\hline RSC & meq/l & -5.89 & -1.55 & -2.89 & 1.07 \\
\hline PI & $\%$ & 20.43 & 33.51 & 28.83 & 3.29 \\
\hline SI calcite & - & 0.13 & 0.43 & 0.26 & 0.09 \\
\hline SI dolomite & - & 1.05 & 1.37 & 1.24 & 0.10 \\
\hline SI gypsum & - & -3.42 & -1.44 & -2.23 & 0.43 \\
\hline SI anhydrate & - & -2.95 & -2.65 & -2.80 & 0.11 \\
\hline
\end{tabular}

water samples from three sites in the southwestern basin have shown nitrate contents greater than the Jordanian standards [25] which set a maximum permissible nitrate content of $70 \mathrm{mg} / \mathrm{l}$ as $\mathrm{NO}_{3}^{-}$(Figure 3). Especially, samples in the Shalha, Karma, Marwan and El-Hasdeh springs were highly contaminated with $\mathrm{NO}_{3}^{-}$(above $100 \mathrm{mg} / \mathrm{l}$ ). Nitrate likely comes from pollution sources such as atmospheric fallout, sanitation facilities, domestic effluents and excess use of fertilization [29] [30]. The increasing number of scattered residences and the high population growth increase the pollution potential of water resources in the study area. The springs were directly influenced by pollution sources through the fissures and fractures associated with the carbonate aquifers. The sulfate, nitrate and chloride contents of the springs have increased sharply during the study period, indicating that pollution, if continued, of springs in the study area in the future would prevent the intended domestic use of these water resources. 
Table 4. Jordanian Standards and WHO guidelines for drinking water quality.

\begin{tabular}{|c|c|c|c|}
\hline Parameters & Units & Jordanian standards [25] & WHO standards [27] \\
\hline $\mathrm{T}$ & $\left({ }^{\circ} \mathrm{C}\right)$ & $12-25$ & $12-25$ \\
\hline $\mathrm{pH}$ & - & $6.50-9.0$ & $6.5-8.5$ \\
\hline $\mathrm{EC}$ & $\mu \mathrm{s} / \mathrm{cm}$ & - & 400 \\
\hline $\mathrm{Na}^{+}$ & $\mathrm{mg} / \mathrm{l}$ & $200-400$ & 200 \\
\hline $\mathrm{Ca}^{2+}$ & $\mathrm{mg} / \mathrm{l}$ & $75-200$ & 100 \\
\hline $\mathrm{Mg}^{2+}$ & $\mathrm{mg} / \mathrm{l}$ & $50-150$ & 50 \\
\hline $\mathrm{K}^{+}$ & $\mathrm{mg} / \mathrm{l}$ & $10-50$ & 20 \\
\hline $\mathrm{HCO}_{3}^{-}$ & $\mathrm{mg} / \mathrm{l}$ & $100-500$ & $125-350$ \\
\hline $\mathrm{Cl}^{-}$ & $\mathrm{mg} / \mathrm{l}$ & $200-500$ & 250 \\
\hline $\mathrm{SO}_{4}^{2-}$ & $\mathrm{mg} / \mathrm{l}$ & $200-500$ & 250 \\
\hline $\mathrm{NO}_{3}^{-}$ & $\mathrm{mg} / \mathrm{l}$ & 70 & 50 \\
\hline TDS & $\mathrm{mg} / \mathrm{l}$ & $500-1500$ & $500-1000$ \\
\hline $\mathrm{TH}$ & $\mathrm{mg} / \mathrm{l}$ & 500 & 500 \\
\hline $\mathrm{Fe}^{2+}$ & $\mathrm{mg} / \mathrm{l}$ & $0.3-1.0$ & 0.3 \\
\hline $\mathrm{Mn}^{2+}$ & $\mathrm{mg} / \mathrm{l}$ & $0.1-0.2$ & $0.1-0.5$ \\
\hline $\mathrm{Zn}^{2+}$ & $\mathrm{mg} / \mathrm{l}$ & $5-15$ & $0.01-3$ \\
\hline $\mathrm{Al}^{3+}$ & $\mathrm{mg} / \mathrm{l}$ & $0.2-0.3$ & 0.2 \\
\hline $\mathrm{Pb}^{2+}$ & $\mathrm{mg} / \mathrm{l}$ & 0.05 & 0.01 \\
\hline $\mathrm{Cu}^{2+}$ & $\mathrm{mg} / \mathrm{l}$ & - & 2 \\
\hline $\mathrm{Cd}^{2+}$ & $\mathrm{mg} / \mathrm{l}$ & - & 0.003 \\
\hline
\end{tabular}

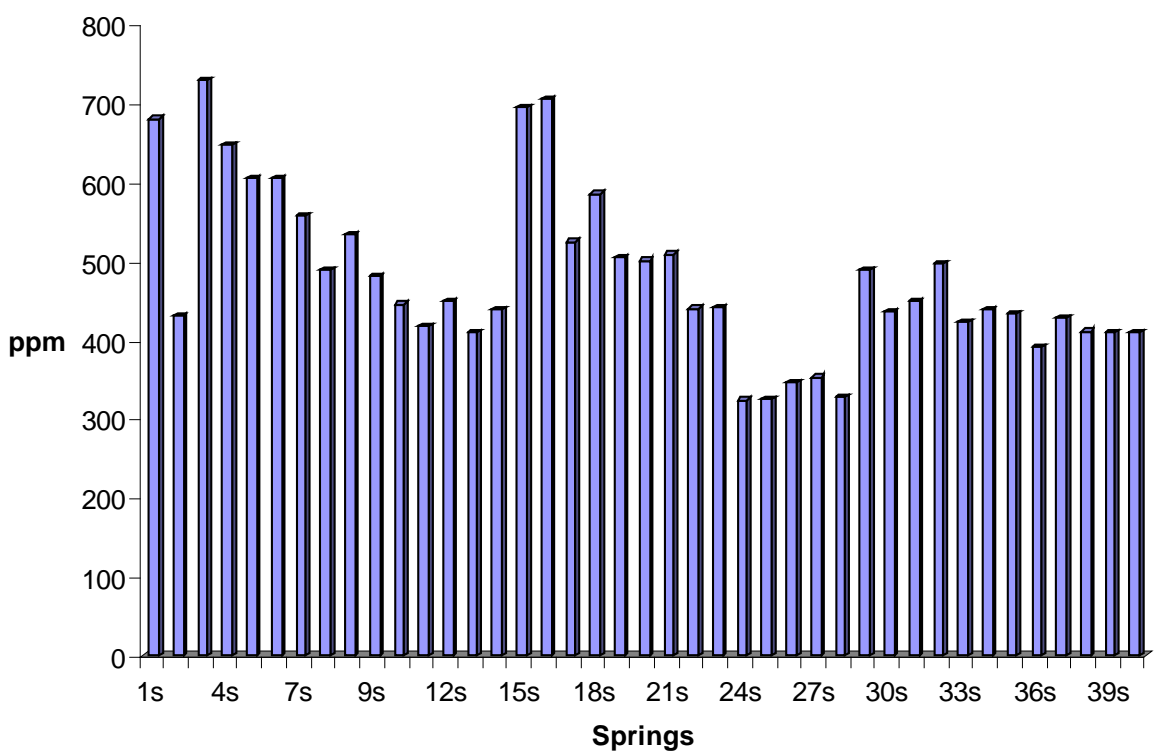

Figure 2. Mean value of TDS levels in spring water samples. 


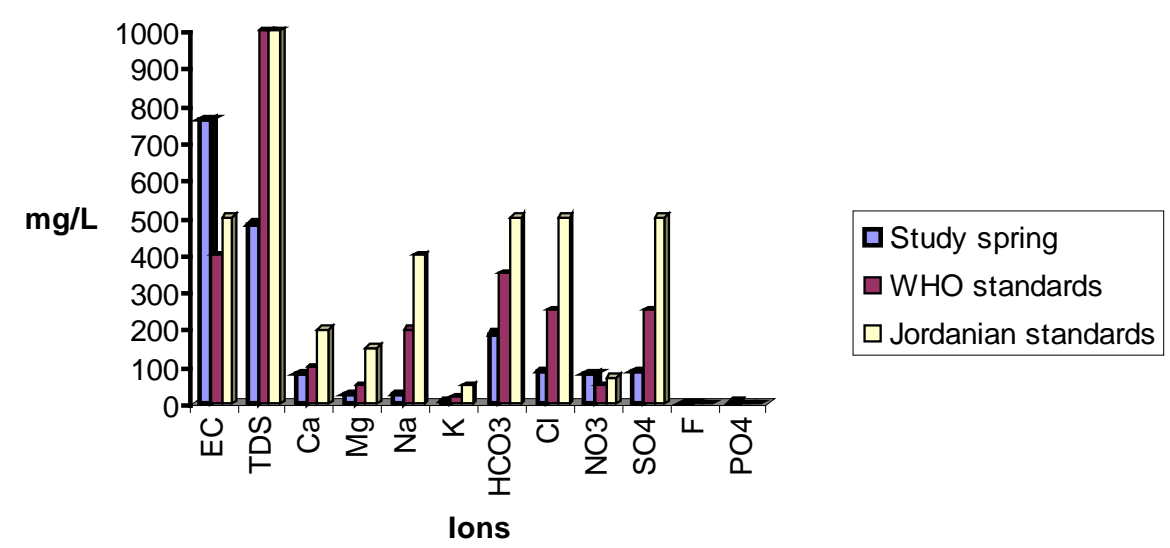

Figure 3. Mean value of ionic compared with Jordanian standard and WHO.

Springs that are located next to the residential areas have been more affected by these points source pollution than other springs. These springs are directly recharged with water. High concentrations of nitrate in the water samples were found in springs located also far away from the cesspools, which indicate that pollution is mainly caused by fertilizers and manure and plant decomposition (Figure 3). Sulfate concentration in the spring's water varied between $42 \mathrm{mg} / \mathrm{l}$ in Mugarayyeh spring and $163.5 \mathrm{mg} / \mathrm{l}$ in Um-Keis spring, with a median value of $85.38 \pm 26.3 \mathrm{mg} / \mathrm{l}$. The high concentration of sulfate in these springs is mainly attributed by anthropogenic activities around the springs.

Chloride concentrations varied from $52 \mathrm{mg} / \mathrm{l}$ in Shammakh spring to $158 \mathrm{mg} / \mathrm{l}$ in Sakeeneh spring (Figure 4). However, high value of chloride in the water samples likely originated from pollution sources such as; domestic effluents, fertilizers, septic tanks and natural sources dissolution of fluid inclusions and $\mathrm{Cl}^{-}$ bearing minerals [21] [29] [30].

In the collected spring-water samples, the highest concentration of bicarbonate was found in Shalha, Um-Garyah, Um-Keis and El-Balad springs. The bicarbonate concentration ranges from $120 \mathrm{mg} / \mathrm{l}$ in Es-Sarab spring to $301 \mathrm{mg} / \mathrm{l}$ in Um-Garyah spring. It seems to be that the increasing $\mathrm{pH}$ values in the spring season was mainly attributed to the increasing of bicarbonate value in spring water samples. The increasing tendency of salinity from summer season (dry season) to the winter and summer season (wet season) was also clearly seen for $\mathrm{Na}^{+}, \mathrm{K}^{+}, \mathrm{Cl}^{-}, \mathrm{NO}_{3}^{-}$and $\mathrm{PO}_{4}^{3-}$. It's related to the concentration of these elements in water springs.

Correlation coefficient is commonly used to measure the relationship between two variables. The statistical analysis showed that $\mathrm{Ca}^{2+}$ has a positive and good correlation with $\mathrm{Mg}^{2+}, \mathrm{Cl}^{-}$and $\mathrm{SO}_{4}^{2-} \quad\left(R^{2}=0.814,0.662\right.$, and 0.721 respectively $)$. $\mathrm{Mg}^{2+}$ was strong positive and significantly correlated with $\mathrm{Cl}^{-}$and $\mathrm{SO}_{4}^{2-}\left(R^{2}=\right.$ 0.824 and 0.710 respectively), sodium was positively correlated with $\mathrm{Cl}^{-}$and $\mathrm{SO}_{4}^{2-} \quad\left(R^{2}=0.751\right.$ and 0.665 respectively $)$. Furthermore, $\mathrm{Cl}^{-}$ions show more significant correlation with $\mathrm{SO}_{4}^{2-}$ and $\mathrm{HCO}_{3}^{-} \quad\left(R^{2}=0.823\right.$ and 0.801 respectively). Phosphate and fluoride ions were not significantly correlated with any of ions studied. 


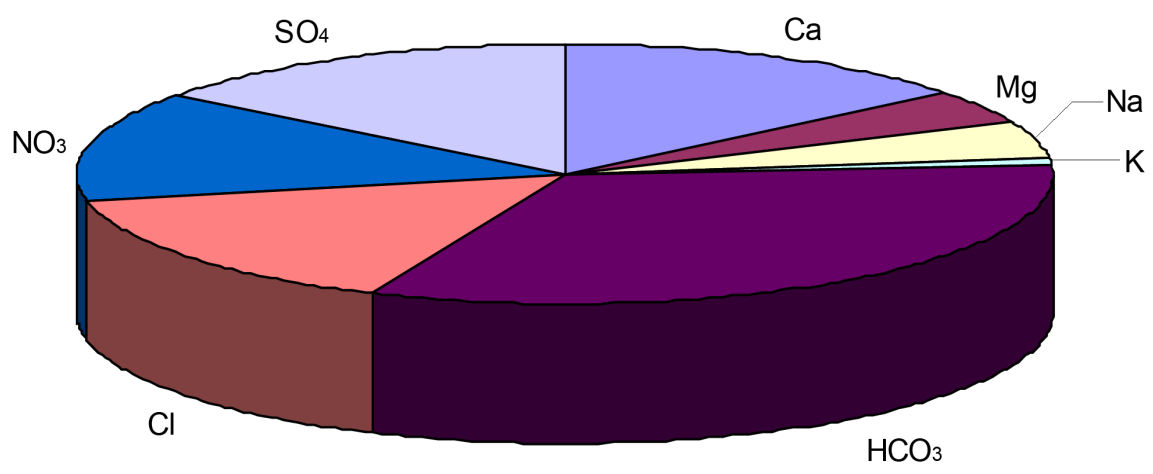

Figure 4. Mean value of ionic composition of springs water samples.

\subsection{Water Chemistry}

Groundwater exchanges ions with the various minerals and gases of the aquifer matrix, which results in dissolution and precipitation of minerals [31]. Saturation indices are used to evaluate the degree of equilibrium between minerals and water. The saturation index of a mineral is obtained by the Equation (1) [32] (Aghazadeh et al., 2010).

$$
S I=\log (A P I / K t)
$$

where $I A P$ is the ion activity product of the dissociated chemical species in solution, $K t$ is the equilibrium solubility product for the chemical involved at the same temperature. When $S I<1$ the minerals will dissolve, on the other hand, the minerals will precipitated when $S I>1$ [12]. The saturation indices for the minerals in the spring water can be expressed by the saturation index $(S I)$. The minerals either dissolve or precipitate when $S I<1$ and $S I>1$ [31] [33]. The summary of statistical analyses of the saturation indices of water samples are presented in Table 3. In all samples, the $S I$ of calcite and dolomite are positive. On the other hand, all of the water samples gave negative values for gypsum and anhydrate indices, which means that all of samples are under saturated with respect to the gypsum and anhydrate and are able to dissolve additional amount of these minerals.

The ion proportions in the samples are shown on the trilinear diagram [34] and then interpreted depending on the classification given by Langguth [35] (Figure 5). The water of springs classifies into two groups: alkaline earth waters with prevailing bicarbonate and alkaline earth waters with prevailing bicarbonate and chloride. The chemistry of water samples shows the following ionic ratio: $\mathrm{Ca}^{2+}>\mathrm{Na}^{+}>\mathrm{Mg}^{2+}>\mathrm{K}^{+}$and $\mathrm{HCO}_{3}^{-}>\mathrm{Cl}^{-}>\mathrm{SO}_{4}^{2-}>\mathrm{NO}_{3}^{-}>\mathrm{PO}_{4}^{3-}>\mathrm{F}^{-}$. Water chemistry originates from dissolution of carbonate rocks. However, the water was generally classified as $\mathrm{Ca}-\mathrm{HCO}_{3}$ with low salinity.

\subsection{Drinking and Irrigation Water Quality}

The analytical results have been evaluated for the suitability of spring water in the investigated area for drinking and agricultural purposes (Table 3). The drinking water quality was evaluated by comparing with the specification of TDS 


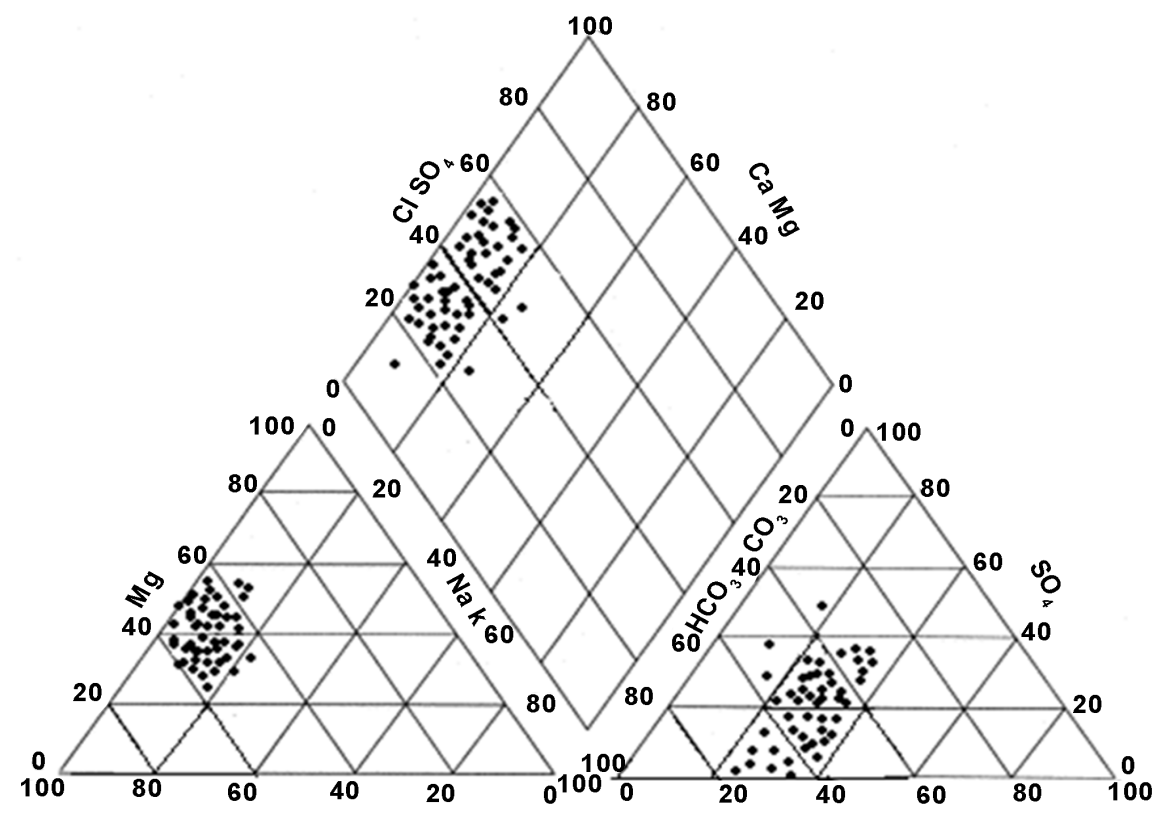

Figure 5. Piper diagram of spring waters in studied area (Values in $\% \mathrm{meq} / \mathrm{l}$ ).

and TH set by the World Health Organization [27] and Jordanian standards [25] (Table 4). In general, all the TDS values of the spring water fall within the permissible limit of Jordanian standards for drinking water [25]. In order to know the suitability of the water for drinking and domestic purposes, the classification of water springs according to Sawyer and McCarty [36] was used. Results show that almost all the samples fall in the category of hard to very hard (Table 5). To solve the water hardness problem, several treatment options can be considered. Among these options are the use of chemical softeners, water filters, and mechanical softeners.

Electrical conductivity is a good measure of salinity in water as it reflects the TDS in groundwater which high concentration causes hazard to crops. The excess of salinity in water reduces the osmotic activity of plants and thus interferes with the absorption of water and nutrients from the soil [37] [38]. The Sodium Adsorption Ratio (SAR) is an important parameter for determining the suitability of groundwater for irrigation purposes, as it is a measure of alkali or sodium hazard to crops. The SAR is defined by the following equation [39].

$$
S A R=\mathrm{Na}^{+} /\left(\mathrm{Ca}^{2+}+\mathrm{Mg}^{2+}\right)^{0.5} / 2
$$

All the concentrations are reported in meq/l.

The $S A R$ values for the analyzed samples range from 0.43 to 1.85 with a mean value of 1.63 , therefore groundwater samples of the study area fall in the low sodium class (S1). The analytical data plotted on the US salinity diagram [40] shows that most of the groundwater samples fall in the field of $\mathrm{C}_{3} \mathrm{~S}_{1}$, indicating a low sodium hazard which can be used for irrigation on almost all types of soil.

The residual sodium carbonate (RSC) represents the excess of carbonate $\left(\mathrm{CO}_{3}^{2-}+\mathrm{HCO}_{3}^{-}\right)$over the calcium ion $\left(\mathrm{Ca}^{2+}+\mathrm{Mg}^{2+}\right)$. The quality of water 
Table 5. Classification of the water samples on the basis of the total hardness.

\begin{tabular}{ccc}
\hline Hardness $(\mathrm{mg} / \mathrm{l})$ & Water class & No. of samples \\
\hline $0-75$ & Soft & - \\
$75-150$ & Moderately hard & 4 \\
$150-300$ & Hard & 450 \\
Over 300 & Very hard & 986 \\
\hline
\end{tabular}

samples has been determined according to the scale of $R S C$ [40]. The RSC is represented in the following equation:

$$
R S C=\left(\mathrm{CO}_{3}^{2-}+\mathrm{HCO}_{3}^{-}\right)-\left(\mathrm{Ca}^{2+}+\mathrm{Mg}^{2+}\right)
$$

All the concentrations are reported in meq/l.

The classification of irrigation water according to the $R S C$ values was shown in Table 3, where the category of groundwater was good. Organic matter is important for the agricultural productivity, the high concentration of $\mathrm{HCO}_{3}^{-}$ leads to an increase in the $\mathrm{pH}$ values causing the dissolution of organic material in the soil. The RSC is used to distinguish between the different water classes for irrigation purposes [41]. The higher value of $\mathrm{HCO}_{3}^{-}$in irrigation water leads to an increase in its toxicity and affects the element nutrition of plants.

On the other hand, the permeability index $(P I)$ values for groundwater samples indicated that the water samples are suitable for irrigation [32] [42]. It is defined as follows (Equation (4)):

$$
P I=100 \times\left[\left([\mathrm{Na}]+\left[\mathrm{HCO}_{3}\right]^{1 / 2}\right)\right] /[\mathrm{Na}]+[\mathrm{Ca}]+[\mathrm{Mg}]
$$

All the ions are expressed in meq/l.

WHO [43] used a criterion for assessing the suitability of water for irrigation based on permeability index. In this study, the $P I$ range from $20.4 \%$ to $33.5 \%$ with an average value of about $28.8 \%$. According to PI values, the groundwater in the investigated area can be classified as class II $(25 \%-75 \%)$ which shows that the water is suitable for irrigation uses.

\subsection{Trace Metals}

Trace metals present in both surface water and groundwater, while the sources of these metals are associated with either natural processes or human activities. Chemical weathering and soil leaching are the two important natural sources contributing to the increase in trace metals concentration in water [12] [44]. Many factors affect the release of trace metals from primary materials and soil, and consequently their stability in water. These factors are $\mathrm{pH}$, adsorption characteristics, hydration and co-precipitation [32] [44]. The statistical analyses of metal contents in the study area are presented in Table 6.

Most of the water samples show low content of trace metals which could be attributed to the high $\mathrm{pH}$ value (higher than $\mathrm{pH}=7$ ) which enhances the deposition of these metals or retarding their dissolution from the rock matrix [10] 
Table 6. Statistical analysis of trace metals of groundwater samples.

\begin{tabular}{cccccc}
\hline Parameters & Units & Minimum & Maximum & Mean & St.Dev \\
\hline $\mathrm{Fe}^{2+}$ & $\mu \mathrm{g} / 1$ & 66.35 & 208.00 & 132.70 & 43.19 \\
$\mathrm{Al}^{3+}$ & $\mu \mathrm{g} / 1$ & 56.40 & 195.00 & 90.53 & 30.82 \\
$\mathrm{Cu}^{2+}$ & $\mu \mathrm{g} / 1$ & 8.50 & 35.80 & 19.41 & 6.58 \\
$\mathrm{Ni}^{2+}$ & $\mu \mathrm{g} / 1$ & 8.65 & 32.00 & 17.95 & 5.60 \\
$\mathrm{~Pb}^{2+}$ & $\mu \mathrm{g} / 1$ & 11.00 & 60.00 & 26.53 & 12.13 \\
$\mathrm{Zn}^{2+}$ & $\mu \mathrm{g} / 1$ & 10.50 & 48.00 & 25.07 & 8.83 \\
$\mathrm{Mn}^{2+}$ & $\mu \mathrm{g} / 1$ & 8.00 & 28.00 & 16.58 & 5.46 \\
\hline
\end{tabular}

[45]. The maximum concentration of iron in water samples was found to be 208 $\mu \mathrm{g} / \mathrm{l}$ at Mugarayyeh spring. The iron concentration generally is low in spring water with strong correlation between oxygen and iron as the latter is mobilized under anoxic conditions. The iron content in the springs is much below the WHO [27] set limit for drinking water (Figure 6). The highest value of lead was measured at Um-Ruweim spring, and the lowest value was recorded in Ifjeij (Fouqa) spring. Most of the springs in the investigated area contain an amount of lead below the tolerance limits $(0.05 \mu \mathrm{g} / \mathrm{l})$ according to the Jordanian standard for drinking water [25]. The mean value of $\mathrm{Mn}$ in the springs ranges from $8 \mu \mathrm{g} / \mathrm{l}$ in Shammakh spring to $28 \mu \mathrm{g} / \mathrm{l}$ in Um-Ruweim spring. The highest value of $\mathrm{Mn}$ was found in Um-Ruweim spring of $28 \mu \mathrm{g} / \mathrm{l}$. This can be explained by point source pollution for municipal waste and septic tanks. However, Mn concentrations in all water samples were found to be lower than the permissible limits for drinking water quality. Zinc concentration in the water springs ranges from $10.50 \mu \mathrm{g} / \mathrm{l}$ in El-Mour spring to $48 \mu \mathrm{g} / \mathrm{l}$ in Shalha spring. All spring water samples contained zinc concentrations that do not exceed the recommended limit according to the Jordanian standard [25] (Figure 6). Other trace metals showed lower concentrations in the collected water samples, indicating lower value than the recommended limit for drinking water.

Finally, the results of this study show that there were considerable variations among the analyzed samples with respect to their physical and chemical parameters, which lie below the maximum permissible levels of the Jordanian standards [25] and World Health Organization [27] drinking water standards. Such variations are attributed to many factors. Among these factors are the variation in depths, aquifers and their physical properties, and samples locations.

\section{Conclusions}

The physical and chemical composition of spring water was studied over a five-year period in the southwestern part of Jordan. The results indicate that spring water is typically alkaline. The chloride, sodium, calcium, bicarbonate and magnesium are the major sources of salinity in the water, while the ion values increased compared with precipitation water due to dissolution of carbonate rocks 


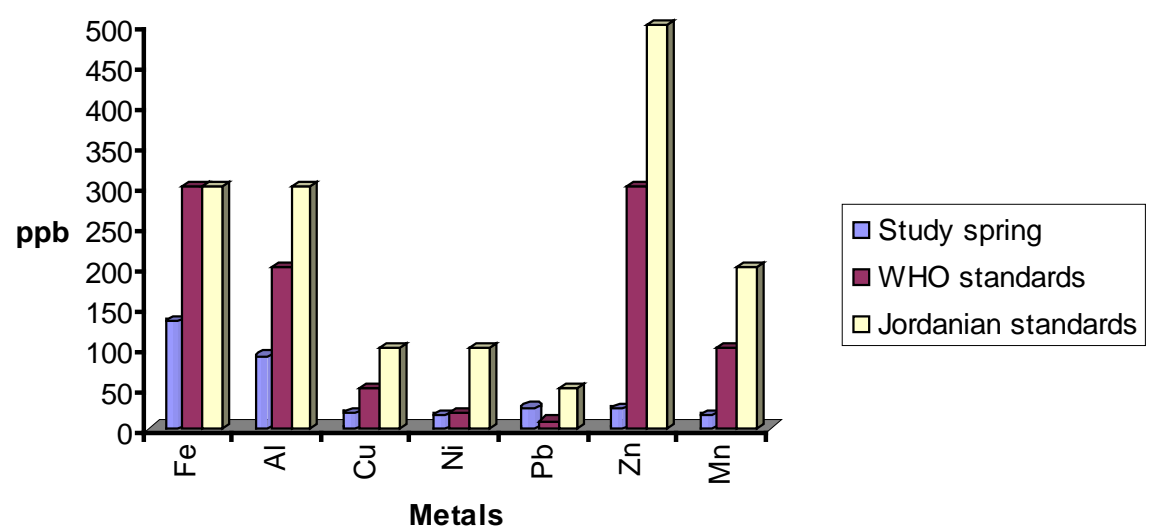

Figure 6. Mean value of metal compared with Jordanian standard and WHO.

and ion exchange processes with rock matrix minerals. The results of this study indicate that the concentration of ions of water are influenced by natural and anthropogenic sources, and indicate that some of the springs are highly polluted with nitrate and sulfate. Point and non-point source pollution of springs are agricultural activities and wastewater recharge from cesspits and septic tanks. Springs located near residential areas have been affected by waste water disposal more than other springs. These springs are directly fed with wastewater through fractures, joints, faults and fissures associated with carbonate aquifers. The water of springs is classified into two groups, alkaline earth waters with prevailing bicarbonate and alkaline earth waters with prevailing chloride. The chemistry of investigated water indicate the ionic ratios of water to be $\mathrm{Ca}^{2+}>\mathrm{Na}^{+}>\mathrm{Mg}^{2+}>\mathrm{K}^{+}$ and $\mathrm{HCO}_{3}^{-}>\mathrm{Cl}^{-}>\mathrm{SO}_{4}^{2-}>\mathrm{NO}_{3}^{-}>\mathrm{PO}_{4}^{3-}>\mathrm{F}^{-}$. Trace metals content in the spring water samples are low due to slightly alkaline water. The study concluded that the trace metals concentrations of the spring waters are much lower than the Jordanian standards and WHO guidelines for drinking waters.

Based on the results of this study, it is highly recommended that the groundwater in the area should be continuously monitored and protection measures must be implemented to alleviate the effects of municipal refuse, wastewater and chemical fertilizers used in agricultural activities. Further studies are also warranted to identify the physical, chemical, biological and organic parameters that are important in monitoring spring and groundwater quality.

\section{References}

[1] Jamshidzadeh, Z. and Mirbagheri, S.A. (2011) Evaluation of Groundwater Quantity and Quality in the Kashan Basin, Central Iran. Desalination, 270, 23-30. https://doi.org/10.1016/j.desal.2010.10.067

[2] Pandey, V.P., Shrestha, S., Chapagain, S.K., and Kazama, F. (2011) A Framework for Measuring Groundwater Sustainability. Environmental Science \& Policy, 14, 396-407. https://doi.org/10.1016/j.envsci.2011.03.008

[3] Angulo, F.J., Tippen, S., Sharp, D.J., Payne, B.J., Collier, C., et al. (1997) A Community Waterborne Outbreak of Salmonellosis and the Effectiveness of a Boil Water Order. American Journal of Public Health, 87, 580-584. 
https://doi.org/10.2105/AJPH.87.4.580

[4] Reda, A.H. (2015) Assessment of Physicochemical Quality of Spring Water in Arbaminch, Ethiopia. Journal of Environmental Analytical Chemistry, 02, No. 05.

[5] Abed, A.M. (2000) The Geology of Jordan and Its Environment and Water (in Arabic). Publication of the Jordanian Geologists Association, Amman.

[6] Baalousha, H. (2010) Assessment of a Groundwater Quality Monitoring Network Using Vulnerability Mapping and Geostatistics: A Case Study from Heretaunga Plains, New Zealand. Agricultural Water Management, 97, 240-246. https://doi.org/10.1016/j.agwat.2009.09.013

[7] Salameh, E. (1996) Water Quality Degradation in Jordan. Royal Society for the Conservation of Nature and Freidrich Ebert Stiftung, Amman.

[8] Department of Meteorology (2006) Internal Report. Department of Meteorology, Amman.

[9] Bender, F. (1974) Geology of Jordan Supplementary Edition in English with Minor Revision. Gebrueder Borntraeger, Berlin, 196.

[10] Al-Khashman, O. (2002) Environmental Status of the Area Extending between Wadi El-Hasa and Wadi Musa from the Railway to Wadi Araba. Ph.D. Thesis, University of Jordan, Amman.

[11] WAJ (2006) Surface Water Resources in Jordan. Unpublished Reports, Water Authority of Jordan, Amman.

[12] Al-Khashman, O.A. (2007) Study of Water Quality of Springs in Petra Region, Jordan: A Three-Year Follow-Up. Water Resources Management, 21, 1145-1163. https://doi.org/10.1007/s11269-006-9073-8

[13] Bandel, K. and Salameh, E. (2013) Geologic Development of Jordan-Evolution of Its Rocks and Life. The University of Jordan Press, Amman, 276 p.

[14] Powell, J. and Moh'd, B. (2011) Evolution of Cretaceous to Eocene Alluvial and Carbonate Platform Sequences in Central and South Jordan. GeoArabia, 16, 29-82.

[15] Macdonald, M. (1965) Hydrogeological Survey of the Madaba-Ma'an Area. Vol. 2, The Water Authority of Jordan, Amman.

[16] Barjous, M.O. (1992) The Geology of the Ash Shawbak Area. Map Sheet No. 3151 III, Bulletin 19, Natural Resources Authority, Amman.

[17] Powell, J.H. (1989) Stratigraphy and Sedimentation of the Phanerozoic Rocks in Central and South Jordan; Part B, Kurnub, Ajlun and Belqa Groups. Geol. Mapping Div. Bull. 11A, Natural Resources Authority, Amman.

[18] Sahawneh, J., Swarieh, A. and Masarweh, R. (2000) Geology and Hydrogeology of the Northern Wadi Araba Basin. Natural Resources Authority, Internal Report No. 11, Amman.

[19] Al-Khashman, O.A., Abu-Hamatteh, Z.S.H., Abu-Nameh, E., Abbassi, B. and Al-Whoosh, K.S. (2010) Environmental Assessment of Spring Water in Tafila District, Southern Jordan: Quality and Chemistry. Water International, 35, 78-93. https://doi.org/10.1080/02508060903504105

[20] Rand, M., Greenberg, A. and Taras, M. (1995) Standard Methods for Examination of Water and Wastewater. 19th Edition, American Public Health Association, Washington DC.

[21] Al-Khashman, O.A. (2007b) Assessment of the Spring Water Quality in the Shoubak Area, Jordan. The Environmentalist, 28, 203-215. https://doi.org/10.1007/s10669-007-9129-1 
[22] Larsen, D., Swihart, G.H. and Xiao, Y. (2001) Hydrochemistry and Isotope Composition of Springs in the Tecopa Basin, Southeastern California, USA. Chemical Geology, 179, 17-35.

[23] Virkutyte, J. and Sillanpää, M. (2006) Chemical Evaluation of Potable Water in Eastern Qinghai Province, China: Human Health Aspects. Environment International, 32, 80-86.

[24] Mouli, P., Venkata Mohan, S. and Reddy, S.J. (2005) Rainwater Chemistry at a Regional Representative Urban Site: Influence of Terrestrial Sources on Ionic Composition. Atmospheric Environment, 39, 999-1008.

[25] Jordanian Standards for Drinking Water (2001) Ministry of Water and Irrigation, Amman, Jordan.

[26] World Health Organization (1996) Guidelines for Drinking Water Quality. 2nd Edition, Vol. 2, Geneva.

[27] World Health Organization (2004) Guidelines for Drinking Water Quality. 3rd Edition, Geneva.

[28] Zacheus, O.M. and Martikainen, P.J. (1997) Physicochemical Quality of Drinking and Hot Waters in Finnish Buildings Originated from Groundwater or Surface Water Plants. Science of the Total Environment, 204, 1-10.

[29] Ritzi, R.W., Wright, S.L., Mann, B. and Chen, M. (1993) Analysis of Temporal Variability in Hydrogeochemical Data Used for Multivariate Analyses. Ground Water, 31, 221-229. https://doi.org/10.1111/j.1745-6584.1993.tb01814.x

[30] Jeong, C.H. (2001) Effect of Land Use and Urbanization on Hydrochemistry and Contamination of Groundwater from Taejon Area, Korea. Journal of Hydrology, 253, 194-210.

[31] Subyani, A.M. (2005) Hydrochemical Identification and Salinity Problem of Ground-Water in Wadi Yalamlam Basin, Western Saudi Arabia. Journal of Arid Environments, 60, 53-66.

[32] Aghazadeh, N. and Mogaddam, A.A. (2010) Assessment of Groundwater Quality and Its Suitability for Drinking and Agricultural Uses in the Oshnavieh Area, Northwest of Iran. Journal of Environmental Protection, 1, 30-40. https://doi.org/10.4236/jep.2010.11005

[33] Fetter, C.W. (1988) Applied Hydrogeology. 2nd Edition, Merrill Publishing Company, London.

[34] Piper, A.M.A. (1953) Graphic Procedure in the Geochemical Interpretation of Water Analysis. Groundwater Note 12, United State Geological Survey.

[35] Langguth, H.R. (1966) Groundwater Verhaltisse in Bereiech Des Velberter. Sattles. Der Minister Fur Eraehrung, Land Wirtsch Forste, NRW, Duesseldorf.

[36] Sawyer, C.N. and McCarty, P.L. (1967) Chemistry and Sanitary Engineers. 2nd Edition, McGraw-Hill, New York.

[37] Saleh, A., Al-Ruwaih, F. and Shehata, M. (1999) Hydrogeochemical Processes Operating within the Main Aquifers of Kuwait. Journal of Arid Environments, 42, 195-209. https://doi.org/10.1006/jare.1999.0511

[38] Subramani, T., Elango, L. and Damodarasamy, S.R. (2005) Groundwater Quality and Its Suitability for Drinking and Agricultural Use in Chithar River Basin, Tamil Nadu, India. Environmental Geology, 47, 1099-1110. https://doi.org/10.1007/s00254-005-1243-0

[39] Karanth, K.R. (1987) Groundwater Assessment, Development and Management. Tata Mc-GrawHill, New Delhi. 
[40] Richards, L.A. (1954) Diagnosis and Improvement of Saline Alkali Soils. US Department of Agriculture Hand Book.

https://doi.org/10.1097/00010694-195408000-00012

[41] Howari, F.M., Abu-Rukah, Y. and Shinaq, R. (2005) Hydrochemical Analyses and Evaluation of Groundwater Resources of North Jordan. Water Resources, 32, 555-564. https://doi.org/10.1007/s11268-005-0071-7

[42] Ragunath, H.M. (1987) Groundwater. Wiley Eastern Ltd., New Delhi.

[43] World Health Organization (1989) "Health Guidelines for the Use of Wastewater in Agriculture and Aquaculture. Report of a WHO Scientific Group-Technical Report Series 778, WHO Geneva, Vol. 74.

[44] Drever, J.F. (1988) The Chemistry of Natural Waters. 3rd Edition, Prentice-Hall, New York.

[45] Al-Awadi, E., Mukhopadhay, A., Akber, M. and Hadi, K. (2003) Distribution of Selected Trace Constituents in the Groundwater of Kuwait. Advances in Environmental Research, 7, 367-380. 